\title{
Tyrosine hydroxylase activity in the endocrine pancreas: changes induced by short-term dietary manipulation María I Borelli ${ }^{1}$, Modesto Rubio $^{2}$, María E García ${ }^{1}$, Luis E Flores ${ }^{1}$ and Juan J Gagliardino*1
}

Address: ${ }^{1}$ CENEXA- Center of Experimental and Applied Endocrinology (National University of La Plata-National Research Council, PAHO/WHO Collaborating Center), School of Medical Sciences, La Plata, Argentina and 2Institute of Pharmacological Investigations (CONICET), Buenos Aires, Argentina

Email: María I Borelli - miborelli@yahoo.com.ar; Modesto Rubio - ininfa@ffyb.uba.ar; María E García - marielisa_ar@yahoo.com.ar; Luis E Flores - fdplf@sinectis.com.ar; Juan J Gagliardino* - gagliardino@infovia.com.ar

* Corresponding author

Published: 24 March 2003

BMC Endocrine Disorders 2003, 3:2
Received: II October 2002

Accepted: 24 March 2003

This article is available from: http://www.biomedcentral.com/1472-6823/3/2

(C) 2003 Borelli et al; licensee BioMed Central Ltd. This is an Open Access article: verbatim copying and redistribution of this article are permitted in all media for any purpose, provided this notice is preserved along with the article's original URL.

\begin{abstract}
Background: Tyrosine hydroxylase (TH) activity and its possible participation in the control of insulin secretion were studied in pancreatic islets of adult Wistar rats fed a standard commercial diet (SD) or carbohydrates alone (CHD) for one week. TH activity, norepinephrine (NE) content, and glucose-induced insulin secretion were assessed. Blood glucose and insulin levels were measured at the time of sacrifice.

Results: CHD rats had significantly higher blood glucose and lower insulin levels than SD rats $(\mathrm{I} \mid 4.5 \pm 6.7$ vs $80.7 \pm 7.25 \mathrm{mg} / \mathrm{dl}, \mathrm{p}<0.00 \mathrm{I} ; 20.25 \pm 2.45$ vs $42.5 \pm 4.99 \mu \mathrm{U} / \mathrm{ml}, \mathrm{p}<0.0 \mathrm{l}$, respectively). Whereas TH activity was significantly higher in CHD isolated islets (600 \pm 60 vs 330 $\pm 40 \mathrm{pmol} / \mathrm{mg}$ protein $/ \mathrm{h} ; \mathrm{p}<0.00 \mathrm{I})$, NE content was significantly lower $(18 \pm \mathrm{I} \mathrm{vs} 3 \mathrm{I} \pm 5 \mathrm{pmol} / \mathrm{mg}$ protein), suggesting that $\mathrm{TH}$ activity would be inhibited by the end-products of catecholamines (CAs) biosynthetic pathway. A similar TH activity was found in control and solarectomized rats ( $330 \pm 40$ vs $300 \pm 80 \mathrm{pmol} / \mathrm{mg}$ protein/h), suggesting an endogenous rather than a neural origin of TH activity. CHD islets released significantly less insulin in response to glucose than SD islets (7.4 \pm 0.9 vs II.4 $\pm \mathrm{I} . \mathrm{I} \mathrm{ng} / \mathrm{islet} / \mathrm{h} ; \mathrm{p}<0.02$ ).

Conclusions: TH activity is present in islet cells; dietary manipulation simultaneously induces an increase in this activity together with a decrease in glucose-induced insulin secretion in rat islets. $\mathrm{TH}$ activity - and the consequent endogenous CAs turnover - would participate in the paracrine control of insulin secretion.
\end{abstract}

\section{Background}

The presence of monoamines in the endocrine pancreas has been reported by several authors in different animals using either histochemical or chemical procedures [1-3], even in islets obtained from chemically sympathectomized mice [4].
Islet cells have also been shown to contain enzymes involved both in catecholamine (CAs) synthesis (tyrosine hydroxylase, TH [5-7], and dihydroxyphenylalanine, DOPA, decarboxylase [6-9]) and inactivation (monoamine oxidase, MAO [10-12]). The increase in islet CAs content in animals previously treated with precursors of CAs 
synthesis [13] would suggest that these enzymes could be actively involved in CAs turnover in islet cells.

The increment of islet CAs - induced by the administration of their precursors - significantly modified the release of insulin, suggesting that endogenous CAs can affect islet function [14]. In support of this assumption we have recently reported that: a) Glucose induces a selective release of CAs by isolated islets, b) TH inhibition by a specific inhibitor increased the glucose-induced insulin secretion from isolated islets in fresh and precultured islets, and c) Addition of $\alpha$ and $\beta$ adrenergic receptor blockers significantly affected the secretion of insulin elicited by glucose [15]. To assess the physiological significance of these results it remains to be elucidated whether they can be reproduced at least partially in vivo.

The present study was designed to gain further insight into the possible role of islet $\mathrm{TH}$ in CAs synthesis and insulin secretion in vivo. Therefore, we tested whether dietary manipulation of normal rats fed only with carbohydrates can modify TH activity, CA content, as well as content and insulin release from isolated islets.

\section{Materials and Methods Chemicals and drugs}

Collagenase was obtained from Serva Feinbiochemica (Heidelberg, Germany); bovine serum albumin fraction $\mathrm{V}$ (BSA) and other reagents of the purest available grade were from Sigma Chemical Co. (St. Louis, MO, USA).

\section{Animals and diets}

Normal male Wistar rats (180-200 g) were maintained in a temperature-controlled environment $\left(23^{\circ} \mathrm{C}\right)$ with a fixed $12 \mathrm{~h}$ light:12 h darkness cycle. The animals were divided into two groups: the intervention group received a carbohydrate diet (CHD) containing 44\% glucose plus $56 \%$ starch (starch composition = carbohydrates:proteins:lipids 27:3.1:0.4) for a week, whereas control rats received a commercial standard diet (SD) containing carbohydrates:proteins:lipids 45:43:12 for the same period. The animals had free access to food and water throughout the experiment. Both weight and food intake were recorded for each individual animal every $48 \mathrm{~h}$ during the experimental period.

\section{Serum glucose and insulin determinations}

Blood samples from both groups of animals were obtained from the retro-orbital plexus under light ether anesthesia early in the morning. Serum glucose was determined by the glucose-oxidase GOD-PAP method (Roche Diagnostics, Mannheim, Germany) and insulin levels were determined by radioimmunoassay (RIA) [16].

\section{Islet isolation and incubation}

Pancreatic islets from SD and CHD rats were isolated by the collagenase method of Lacy and Kostianovsky [17]. Groups of five islets from both groups were incubated for $60 \mathrm{~min}$ at $37^{\circ} \mathrm{C}$ in $600 \mu \mathrm{l}$ Krebs-Ringer-bicarbonate buffer with $1 \%(\mathrm{w} / \mathrm{v})$ BSA, Trasylol ${ }^{\mathrm{TM}}(400 \mathrm{IU} / \mathrm{ml})$, and either 3.3 or $16.7 \mathrm{mM}$ glucose [18]. The medium had been previously gassed with a mixture of $\mathrm{CO}_{2} / \mathrm{O}_{2}(5 \% / 95 \%)(\mathrm{v} / \mathrm{v})$ to adjust the $\mathrm{pH}$ to 7.4 ; aliquots were obtained from the medium at the end of the incubation period and kept frozen until insulin determination by RIA [16].

\section{Islet insulin content}

Groups of 20 isolated islets were placed in $400 \mu \mathrm{l} \mathrm{H} 2 \mathrm{O}$. After disruption by ultrasound for $15 \mathrm{~s}$, the samples were diluted with two volumes of $30 \%$ (v/v) acetic acid. Suitable further aliquots at appropriate dilutions were then used to measure insulin levels by RIA [16].

\section{TH activity assay}

SD and CHD islets were placed in a tube containing Locke's solution and then disrupted with a glass homogenizer in a $150 \mathrm{mM} \mathrm{KCl}$ solution $(1 / 10[\mathrm{w} / \mathrm{v}])$ in the cold. Of this homogenate, $150 \mu$ l were used as the source of enzyme in all experiments. The incubation medium had the following composition (in a total volume of $0.5 \mathrm{ml}$ ): 400 mM sodium-acetate buffer, $\mathrm{pH} 6.1 ; 1.0 \mathrm{mM} \mathrm{FeSO}_{4} 40 \mathrm{mM}$ 2-mercaptoethanol; $100 \mu \mathrm{M}$ or $2.0 \mathrm{mM} \mathrm{DMPH}_{4}$ (2-amino-4-hydroxy-6,7-dimethyl-5,6,7,8-tetrahydropteridine hydrochloride); $2.0 \mathrm{mM}$ sodium phosphate; 15 units $/ \mathrm{ml}$ DOPA decarboxylase; $10 \mu \mathrm{M}$ pyridoxal phosphate; 100 $\mu \mathrm{M}\left[1{ }^{14} \mathrm{C}\right] \mathrm{L}$-tyrosine $(10 \mathrm{Ci} / \mathrm{mol}$, New England Nuclear Corporation, Boston, USA). Blanks were obtained by performing the assay in the presence of $2 \mathrm{mM}$ of the inhibitor 3 -iodotyrosine in the incubation medium. The reaction was carried out for $30 \mathrm{~min}$ at $37^{\circ} \mathrm{C}$ with continuous shaking in a $10 \mathrm{ml}$ Erlenmeyer flask covered with a rubber injection-vial stopper from which a plastic well was suspended containing a folded paper impregnated with $0.2 \mathrm{ml}$ NCS (Nuclear Chicago solubilizer) in order to trap the ${ }^{14} \mathrm{CO}_{2}$ formed in the decarboxylation step of the assay [19].

The reaction was stopped by injecting $0.5 \mathrm{ml}$ of $10 \%(\mathrm{v} / \mathrm{v})$ trichloroacetic acid into the flask. The incubation was next resumed for $2 \mathrm{~h}$ at $37^{\circ} \mathrm{C}$ with continuous shaking to trap the ${ }^{14} \mathrm{CO}_{2}$ released by the enzymic reactions. The plastic wells were then removed, wiped with absorbent tissue, and placed in $10 \mathrm{ml}$ toluene scintillation fluid containing $0.6 \mathrm{~g}$ 1,4-bis-[2 (5-phenyloxazolyl)]benzene (POPOP), $4 \mathrm{~g}$ 2,5-diphenyloxazole (PPO), and $5 \mathrm{ml}$ ethanol per liter of toluene. The samples were finally counted in a liquidscintillation spectrometer. 

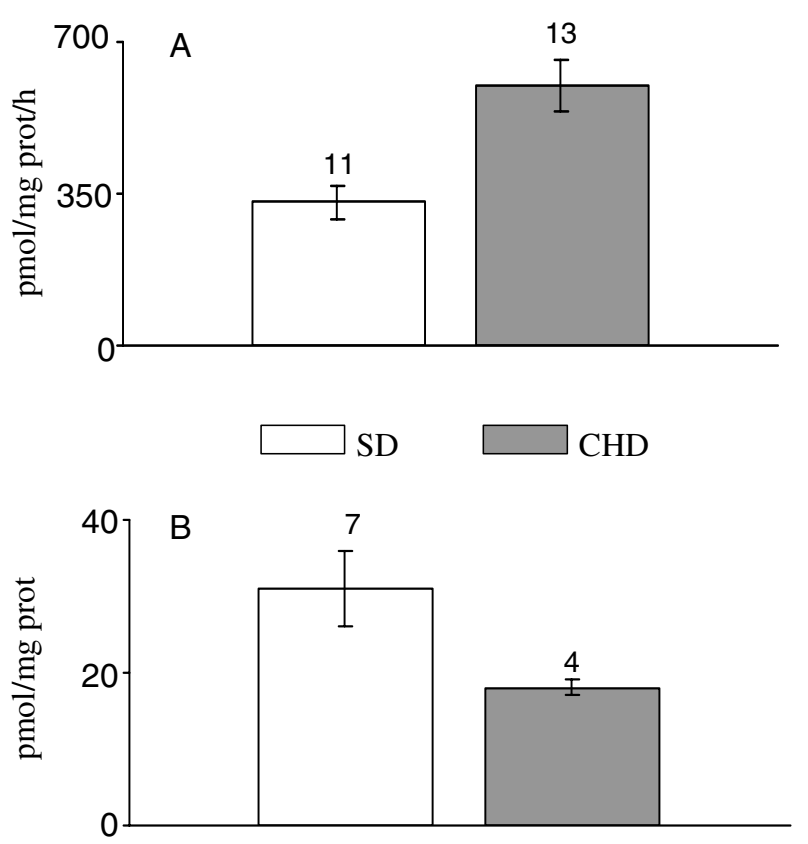

\section{Figure I}

Effect of CHD upon TH activity (pmol/mg protein/h) [panel A], and NE content (pmol/mg prot) [panel B] of normal rat isolated islets of Langerhans (SD, open bars; CHD, hatched bars). Each bar represents the mean \pm SEM. $n$, above the corresponding bar. $P$ values: TH activity, $p<0.00 I ;$ NE content, $p<0.05$.

\section{CA quantitation}

NE was partially purified by batch alumina extraction, separated by reverse-phase HPLC on a 4.6 X 250-mm Zorbax RP C 18 column (DuPont), and quantified amperometrically with a triple-electrode system (ESA, Bedford, NA) by measuring the current produced upon exposure of the column effluent to first oxidizing and then reducing potentials in series. CAs recovery through the alumina-extraction step averaged some $70-80 \%$, as estimated through the use of dihydroxybenzylamine as internal standard [20].

\section{Data analysis}

For the statistical evaluation of the data, we used both variance analysis and the paired Student's t-test.

\section{Results}

Although both groups of rats ate comparable amounts of their respective diets, there was an $8 \%$ body weight increase in the SD group $(214.3 \pm 4.1$ to $231.7 \pm 4.4 \mathrm{~g})$, while CHD animals underwent a $13 \%$ weight loss $(270.7$ \pm 7.6 to $233.8 \pm 6.3 \mathrm{~g}$ ). The caloric content of the daily food consumed per animal was significantly lower in CHD rats $(58.8 \pm 3.5$ vs $152 \pm 15.2 \mathrm{Cal} / \mathrm{d}, \mathrm{p}<0.01)$

Serum glucose and insulin levels measured at the time of sacrifice were significantly higher and lower, respectively, in the CHD than in the SD group (glucose, $114.5 \pm 6.7$ ( $\mathrm{n}$ $=6)$ vs $80.7 \pm 7.25(\mathrm{n}=6) \mathrm{mg} / \mathrm{dl}, \mathrm{p}<0.001$; insulin, 20.25 \pm 2.45 vs $42.5 \pm 4.99 \mu \mathrm{U} / \mathrm{ml}, \mathrm{p}<0.01)$. 


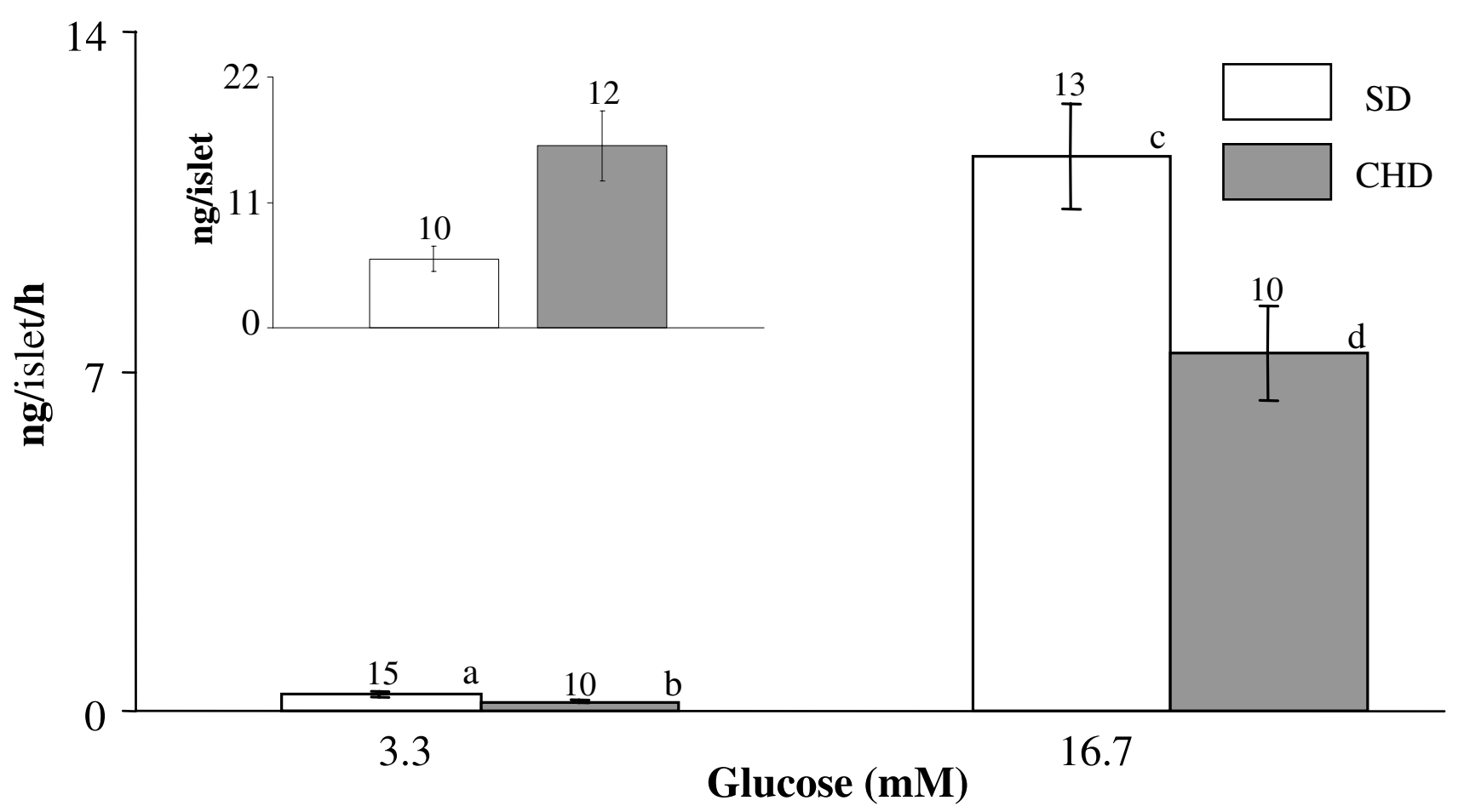

\section{Figure 2}

Effect of CHD upon insulin secretion (ng/islet/h) of isolated normal rat islets incubated in the presence of 3.3 or $16.7 \mathrm{mM}$ glucose (SD, open bars; CHD, hatched bars). Each bar represents the mean \pm SEM. $n$, above the corresponding bar. $P$ values: a vs $c$ and b vs d, $p<0.00$ I; c vsd, $p<0.02$. Inset: Insulin content of nonincubated islets isolated from animals of the indicated group. Each bar represents the mean \pm SEM, $n$ above the corresponding bar. $P<0.005$.

Islet TH activity of CHD rats was significantly higher than that of SD controls (Fig. 1A, p < 0.001). Conversely, no significant differences between these two groups were observed when TH activity was measured in samples of cardiac muscle (data not shown). Similar TH activity values were measured in previous control experiments in islets isolated from normal $(\mathrm{N})$ or solarectomized $(\mathrm{S})$ rats $(\mathrm{N}=$ $330 \pm 40$ vs $S=300 \pm 80 \mathrm{pmol} / \mathrm{mg}$ prot $/ \mathrm{h})$.

NE content of islets obtained from CHD rats was significantly lower than that of SD animals (Fig 1B; $p<0.05$ ).

Islets isolated from both groups released more insulin in response to 16.7 than $3.3 \mathrm{mM}$ glucose $(\mathrm{p}<0.001)$; however, islets from CHD animals released significantly less insulin in the presence of high glucose than did those from SD rats $(\mathrm{p}<0.02)$. By contrast, a similar insulin output by the islets of both groups was observed in response to $3.3 \mathrm{mM}$ glucose (Fig. 2). However, the insulin content of nonincubated islets freshly isolated from CHD rats was significantly higher than that SD rat islets (Fig 2, inset; $\mathrm{p}<$ 0.05).

\section{Discussion}

Teitelman et al. [21] originally demonstrated the immunocytochemical presence of TH in glucagon- and insulinsecreting cells of the fetal mouse pancreas and its disappearance after birth. Using the same method, however, Iturriza \& Thibault [5] detected TH in B-cells of Sprague Dawley rats, two strains of mice, and pigmented guinea 
pigs, suggesting that the expression of TH in the mammalian endocrine pancreas was not necessarily a transient phenomenon.

Our study is the first to demonstrate a measurable and modulated TH activity in the endocrine pancreas of normal adult rats. Since similar TH activity values were recorded in islets isolated from S and SD rats, the enzyme activity measured was of islet rather than neural origin. The increase in islet TH activity measured in our CHD islets could be ascribed to the reported stimulatory effect of this type of diet upon the sympathetic activity and on pancreatic - and other tissues as well - NE turnover [22] in man and rats [23]. However, the fact that this diet did not affect TH activity in cardiac muscle would indicate a selective effect upon islet CAs. The possibility that CAs metabolism exhibits a lower response threshold to dietary manipulations in islets than in other peripheral tissues cannot be ruled out.

In CHD animals, the increased islet TH activity was accompanied by a decreased NE content [24]. In other tissues, the limiting step in CA biosynthesis is the conversion of tyrosine to DOPA by TH [25], being this reaction inhibited by the end products of the biosynthetic pathway [26]. Thus, though with caution, we could assume that a similar regulatory mechanism would also operate in vivo in normal islets. However, we cannot assure that exposure to the diet for a week would not induce TH synthesis de novo [26].

The islets from CHD animals released less insulin than those from SD rats when incubated with $16.7 \mathrm{mM}$ glucose. This lower response was not secondary to a decrease in the storage of the hormone, since the islets from CHD rats contained a higher concentration of insulin than did those from the SD group. These results are consistent with those reporting that monoamines in B cells do not influence insulin storage [27]. The significantly higher blood glucose and lower insulin levels measured in CHD animals would represent the in vivo counterpart of the lower capacity of their islets to release insulin in response to glucose in vitro. These results are also consistent with our report that a specific TH inhibitor increased significantly the glucose-induced insulin release either in fresh or precultured incubated islets [15], suggesting that the phenomenon could also occur in vivo. However, we cannot rule out that the caloric restriction and the protein deficiency in CHD animals could also affect through another mechanism the in vitro glucose-induced insulin secretion in this group of rats $[28,29]$.

Altogether, our results are consistent with the following conclusions: a) TH activity in pancreatic islets can be modified, at least by dietary manipulation; b) As in other tissues, the activity of the enzyme would be inhibited by the end products of the CA biosynthetic pathway, and c) Changes in TH activity of isolated islets are accompanied by significant alterations in the amount of insulin released in vitro in response to glucose, a functional association that may also occur in vivo. These findings, together with those previously reported [15], would indicate that endogenously-generated islet CAs might well participate in the paracrine control of insulin secretion.

\section{Competing interests}

None declared.

\section{Acknowledgments}

This study was supported by grants provided by CONICET and CICPBA. The authors are grateful to A Di Maggio for excellent secretarial support, and A Díaz for careful technical assistance.

\section{References}

I. Falck B and Hellman B Evidence for the presence of biogenic amines in pancreatic islets Experientia 1963, 19:139-140

2. Falck $B$ and Hellman $B$ A fluorescent reaction for monoamines in the insulin producing cells of the guinea pig Acta Endocrinol (Copenh) 1964, I:133-138

3. Cegrell $L$ The occurrence of biogenic monoamines in the mammalian endocrine pancreas Acta Physiol Scand Suppl 1968, 3I4:I-60

4. Lundquist I, Ahren B, Hansson C and Hakanson R Monoamines in pancreatic islets of guinea pig, hamster, rat, and mouse determined by high performance liquid chromatography Pancreas 1989, 4:662-667

5. Iturriza FC and Thibault J Immunohistochemical investigation of tyrosine-hydroxylase in the islets of Langerhans of adult mice, rats and guinea pigs Neuroendocrinology 1993, 57:476-480

6. Teitelman $\mathrm{G}$ and Lee JK Cell lineage analysis of pancreatic islet development: glucagon and insulin cells arise from catecholaminergic precursors present in the pancreatic duct Dev Biol 1987, I 2 I:454-466

7. Teitelman G, Alpert S, Polak JM, Martínez A and Hanahan D Precursor cells of mouse endocrine pancreas coexpress insulin, glucagon, and the neuronal proteins tyrosine hydroxylase and neuropeptide $\mathbf{Y}$, but not pancreatic polypeptide Development 1993, II 8:1031-1039

8. Teitelman G, Lee JK and Alpert S Expression of cell type-specific markers during pancreatic development in the mouse: implications for pancreatic cell lineages Cell Tissue Res 1987, 250:435-439

9. Borelli MI, Villar MJ, Orezzoli A and Gagliardino JJ Presence of DOPA decarboxylase and its localization in adult rat pancreatic islet cells Diabetes Metab 1997, 23:161-163

10. Lenzen $\mathrm{S}$, Nahrstedt $\mathrm{H}$ and Panten $U$ Monoamine oxidase in pancreatic islets, exocrine pancreas, and liver from rats. Characterization with clorgyline, deprenyl, pargyline, tranylcypromine, and amezinium Naunyn Schmiedebergs Arch Pharmacol 1983, 324:190-195

II. Stenström A, Panagiotidis $G$ and Lundquist I Monoamine oxidase (MAO) in pancreatic islets of the mouse: some characteristics and the effect of chemical sympathectomy Diabetes Res 1989, I I:8I-84

12. Stenström A and Lundquist I Monoamine oxidase (MAO) A and $B$ in pancreatic islets from the mouse Biogenic Amines 1990 , 6:547-555

13. Ericson LE, Hakanson $R$ and Lundquist I Accumulation of dopamine in mouse pancreatic B-cells following injection of L-DOPA. Localization to secretory granules and inhibition of insulin secretion Diabetologia 1977, 13:1 17-124

14. Zern RT, Bird JL and Felman JM Effect of increased pancreatic islet norepinephrine, dopamine and serotonin concentration on insulin secretion in the golden hamster Diabetologia 1980, I8:34|-346 
15. Borelli MI and Gagliardino || Possible modulatory effect of endogenous islet catecholamines on insulin secretion BMC Endocrine Disorders 200I, I(I):I

16. Herbert V, Lau KS, Gottlieb CW and Bleicher SI Coated-charcoal immunoassay of insulin J Clin Endocrinol Metab 1965, 25: I 375- 1384

17. Lacy PE and Kostianovsky M Method for the isolation of intact islets of Langerhans from the rat pancreas Diabetes 1967, 16:35-39

18. Gagliardino J], Nierle C and Pfeiffer EF The effect of serotonin on in vitro insulin secretion and biosynthesis in mice Diabetologia 1974, 10:4II-4I4

19. Waymire JC, Bjur R and Weiner N Assay of tyrosine hydroxylase by coupled decarboxylation of DOPA formed from I $\left[{ }^{14} \mathrm{C}\right]-$ L-tyrosine Anal Biochem I97I, 43:588-600

20. Eisenhofer G, Goldstein DS, Stull R, Keiser HR, Sunderland T, Murphy DL and Kopin IJ Simultaneous liquid-chromatographic determination of 3,4-dihydroxyphenylglycol, catecholamines, and 3,4-dihidroxyphenilalanine in plasma, and their responses to inhibition of monoamine oxidase Clin Chem 1986, 32:2030-2033

21. Teitelman G, Joh TH and Reis DJ Transformation of catecholaminergic precursors into glucagon (A) cells in mouse embryonic pancreas Proc Natl Acad Sci 1981, 78:5225-5229

22. Young JB and Lansberg $L$ Effect of diet and cold exposure on norepinephrine turnover in pancreas and liver Am J Physiol 1979, 236:E524-E533

23. Landsberg L, Greff L, Gunn S and Young JB Adrenergic mechanisms in the metabolic adaptation to fasting and feeding: effects of phlorizin on diet-induced changes in sympathoadrenal activity in the rat Metabolism 1980, 29(Suppl I): I I 28-1 I 37

24. Gagliardino JJ, Borelli Ml and Rubio M Possible role of endogenous islet catecholamines in the paracrine control of insulin secretion Diabetologia 1996, 39(SuppI I): I I28-I I 37

25. Levitt M, Spector S, Sjoerdsma A and Udenfriend S Elucidation of the rate limiting sep in norepinephrine biosynthesis in the perfused guinea pig heart J Pharmacol Exp Ther 1965, I 48: I-8

26. Weiner N and Molinoff PB Catecholamines. In: Siegal GJ, ed. Basic Neurochemistry, Molecular, Cellular an Medical Aspects New York: Raven Press 1989,

27. Lundquist $Y$, Sundler $F$ and Hakanson $R$ Differential changes in the 5-hydrosytryptamine and insulin content of guinea pig B cells Endocrinology 1975, 97:937-947

28. Swenne I, Borg LA, Crace CJ and Schnell Landstrom A Persistent reduction of pancreatic beta-cell mass after a limited period of protein-energy malnutrition in the young rat Diabetologia 1992, 35:939-945

29. Picarel-Blanchot F, Alvarez C, Bailbe D, Pascual-Leone AM and Portha $B$ Changes in insulin action and insulin secretion in the rat after dietary restriction early in life: influence of food restriction versus low-protein food restriction Metabolism 1995, 44:15I9-1526

\section{Pre-publication history}

The pre-publication history for this paper can be accessed here:

http://www.biomedcentral.com/1472-6823/3/2/prepub

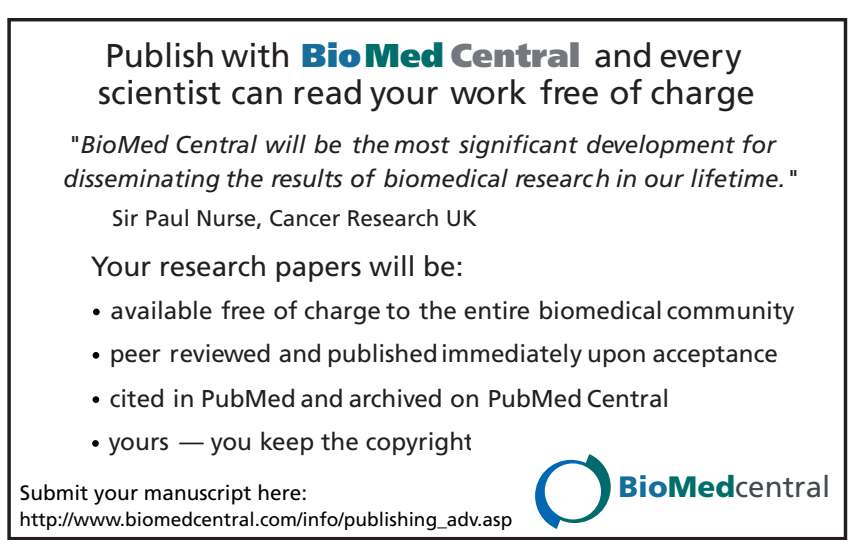

